\title{
Az Egészségügyi Világszervezet öttételes jól-lét kérdőívének vizsgálata a Semmelweis Egyetem elsőéves hallgatóinak körében
}

\author{
Dinyáné Szabó Mariann ${ }^{1}$ - Pusztai Gabriella dr. ${ }^{2}$ \\ ${ }^{1}$ Semmelweis Egyetem, Egészségügyi Közszolgálati Kar, Digitális Egészségtudományi Intézet, Budapest \\ ${ }^{2}$ Debreceni Egyetem, Neveléstudományok Intézete, Debrecen
}

\begin{abstract}
Bevezetés: A felsőoktatásban tanuló hallgatók jól-létének vizsgálata a nemzetközi kutatások érdeklődési körébe került, mert a felnőttkori egészség, mint érték, fontos szerepet játszik a jövő generációjának életében. Célkitüzés: A szerzők orvos- és egészségtudományi tanulmányaikat megkezdő hallgatók körében vizsgálták a hallgató jól-lét értékét befolyásoló változókat (élettel való elégedettség, hallgatói eredményesség, egyetemi infrastruktúrával való elégedettség, sport, szülő́k anyagi helyzete). Módszer: A jól-lét mérésére az Egészségügyi Világszervezet WBI-5 (Általános Jól-lét Index, 5 tételes) magyar változatát használták. A WBI-5 belső megbízhatósága magas (Cronbach-alfa: 0,778 ). Eredmények: A kérdőiv rotálatlan fókomponens-elemzése megerősíti a kérdőív homogenitását, az adatbázis használhatóságát (Kaiser-Meyer-Olkin-index $=0,748$; Bartlett-teszt $<0,0001)$. Lineáris regresszió alkalmazásával $\left(\mathrm{R}=0,458, \mathrm{R}^{2}\right.$ $=0,2 \mathrm{l}, \mathrm{F}=16,33, \mathrm{p}=0,001$, a VIF-értékek $\mathrm{l}$ körüliek) kiszúrve a válaszokból azokat a magyarázó változókat, amelyek a legjobban befolyásolják a függő változó, a WBI-5 értékét: 1 . pozitív lineáris kapcsolatot mutat a karral, az SWLS-pontszámmal, a sportolással, az egyetemi infrastruktúrával való elégedettséggel; 2 . negatív lineáris kapcsolatot mutat a nemmel, a szülók anyagi helyzetével. Következtetés: A hallgatók jól-lét vizsgálata segítséget adhat a karoknak, az oktatóknak a hallgatóikban rejlő lehetőségek kibontakoztatásához, a feleslegesen stresszt okozó helyzetek kiküszöböléséhez. Orv. Hetil., 2016, 157(44), 1762-1768.
\end{abstract}

Kulcsszavak: felsőoktatás, WHO WBI-5, SWLS, jóllét

\section{Use of the short (5-item) version of the WHO well-being questionnaire in first year students of Semmelweis University}

Introduction: Studies on well-being of students in higher education are in the centre of international research interest, because adult health as a value plays an important role in the life of future generation. Aim: The authors studied variables that affect the value of well-being (satisfaction with life, student success, satisfaction with academic infrastructure, sports and financial situation of parents) among medical and health science students starting their studies. Method: The Hungarian version of the Word Health Organization WBI-5 (General Well-Being Index, 5-item version) were used. This questionnaire has a high internal reliability (Cronbach's alpha: 0.778). Results: The unrotated principal component analysis of the questionnaire survey confirmed the homogeneity of the database utility (KaiserMeyer-Olkin-index $=0.748$; Bartlett test $<0.0001)$. On the basis of stepwise linear regression $\left(\mathrm{R}=0.458, \mathrm{R}^{2}=0.21\right.$, $\mathrm{F}=16.33, \mathrm{p}=0.001$, VIF values around 1 ) showed (i) a positive relationship with explanatory variables such as faculty and sport activity, satisfaction with life scale and university infrastructure, and (ii) a negative relationship with gender and parental substance. Conclusion: The authors conclude that short Well-Being Index is a reliable and valid instrument to measure positive quality of life of medical students. Furthermore, the Well-Being Index can help university faculties and lecturers to deploy the student facilities and to eliminate the harm of stress situations.

Keywords: higher education, WHO WBI-5, SWLS

D. Szabó, M., Pusztai, G. [Use of the short (5-item) version of the WHO well-being questionnaire in first year students of Semmelweis University]. Orv. Hetil., 2016, 157(44), 1762-1768.

(Beérkezett: 2016. július 21.; elfogadva: 2016. augusztus 18.) 


\section{Rövidítések}

ÁOK = Általános Orvostudományi Kar; BSc (Bachelor of Science $)$ = föiskolai szintű diploma; $\mathrm{df}=$ szabadsági fok; $\mathrm{EKK}=$ Egészségügyi Közszolgálati Kar; FOK = Fogorvos-tudományi Kar; GYTK = Gyógyszerész-tudományi Kar; PCA = fookomponens-analízis; SWLS $=$ (Satisfaction With Life Scale) Élettel Való Elégedettség Skála; $\mathrm{t}=\mathrm{t}$-statisztika; WHO WBI-5 = 5-item WHO Well-Being Index ( 5 tételes WHO Általános Jóllét Index)

A jövő gyógyítói és az egészségügy más területein dolgozni szándékozók a jelen orvosi, egészségügyi oktatás hallgatói. Ök azok, akiknek az egyetemi éveik alatti egészsége kihat a jövő társadalmának egészségére is, hiszen ezek a hallgatók, mint potenciális egészségügyi szakemberek, mint a jövő egészségügyét formáló döntéshozók vesznek majd részt a munka világában. Képzésük olyan társadalmi befektetés, amely csak akkor térül meg, ha a végzett hallgatók az elsajátított professzionális ismereteikkel, egészségesen tudnak munkába állni, és ott, ahová kiképezték óket [1].

Nemzetközi kutatások azt mutatják, hogy a magasabb jól-lét érzésű hallgatók hatékonyabban tanulnak, jobban oldják meg a tanulmányok alatt jelentkező - stresszkeltô - problémákat, és ezáltal a tanulmányok befejezése után nagyobb a valószínűsége annak, hogy egészséges személyiségként veszik fel a társadalmi, szakmai, vezetói szerepeket [2]. A felsőoktatásban - a nem tradicionális hallgatók létszámának növekedésével számolva - a hallgatói és intézményi célok magvalósulását jobban segítheti a hallgatói egészség és jól-lét gondozása, hiszen a hallgató testi, lelki és érzelmi jól-léte az eredményes tanulás meghatározó tényezője [3].

Az egyén akkor egészséges, ha az életmúködései az adott környezetben kiegyensúlyozottak, a lelki élete harmonikus és a társadalmi környezet vele szemben támasztott elvárásainak meg tud felelni. A WHO definíciója (1946) szerint az egészség a teljes testi, lelki és szociális jól-lét állapota, és nem csupán a betegség hiánya vagy fogyatékosság [4]. Ebből következően az egyén jól-léte a saját maga által, a környezete által, valamint a társadalom által befolyásolt olyan állapot, amelyen az élettel való általános elégedettség, a közösségbeli részvétel, az eredményesség, annak szubjektív érzése értendő, amelyben az egyén belső világában rejlő jellemzők is szerepet kapnak [5].

A jól-lét - Diener definíciója szerint - magába foglalja a boldogságot, az élettel való megelégedettséget, a pozitív érzelmi tényezőket, valamint számos szociális és egészségügyi haszonnal társul és kihívásokat tartalmaz [6]. A jól-lét felfogható mint pozitív lelki egészség. Sok tanulmány foglalkozik a hiánya miatt bekövetkezö öngyilkosság és depresszió veszélyével, amelyek tünetei már az egyetemista életszakaszban is megjelenhetnek $[7,8]$.

A hallgatói jól-lét is olyan összetett konstrukció, amelynek mentális, érzelmi, lelki, szociális és fizikai aspektusai vannak, amelyek szorosan összefüggnek egy- mással, és együttmúködnek egy „kiegyensúlyozott egész részeiként". Állandó balanszírozásra van szükség, miközben a részterületek növekedésével és integrálódásával fejlődik maga az „egész” [9]. A felsőoktatásba való bekerüléssel növekszik a hallgatót érő stresszhatások száma, valamint az ezek erôssége: nő az önálló döntéseik száma, a kapcsolataik átrendeződnek, az új környezetbe való beilleszkedés is erős stresszfaktor stb. A nem megfelelő megküzdési mód megválasztása negatív stresszkezelési szokások kialakulásához vezethet, amelyeket meg kell próbálni megelőzni az egyénnek is és a környezetnek is [10].

Az egyének akkor tudják befolyásolni a saját jól-lét érzésüket, ha van megfelelő önismeretük, és így tudatosan élik az életüket, felismerik a vágyaikat, kielégítik a szükségleteiket és alkalmazkodni tudnak a változásokhoz. Ilyen értelmezésben az egészség saját erőforrásként jelenik meg [11]. Ebben a felfogásban az egyetemi hallgatók jól-léte úgy is jellemezhető, hogy képesek optimalizálni önmaguk és mások egészségét és képességeit, és eredményesnek érzik magukat [12].

A „tanult sikeresség” (eredményesség) - mint készség - elsajátítása a hallgatói időszak alatt növeli a hallgatók megküzdőképességét, az élettel való elégedettségét, a magasabb jól-lét érzetet és megelőzésként hathat a stressz okozta megbetegedések kialakulására. A későbbi, segítő munkájukat is hatékonyabbá teheti, ha a hozzájuk fordulókban is ezt az attitúdöt tudják kialakítani [13, $14]$.

A pozitív pszichológia szemléletét követve, azokat a tényezőket kutatjuk, amelyek az egyének és a hallgatói közösségek jól-létét elősegítik és prediktívek [15]. A hallgatói jól-lét érzetet előnyösen befolyásolja az élettel való szubjektív elégedettség, a sportolás, mint a saját egészséggel való törődés [16], a szülők anyagi helyzete, az intézményi környezettel való elégedettség. A karok, csoportok közössége nagymértékben elősegítheti az egyéni és közösségi - pozitív - célok elérésének lehetôségét [17], valamint lehetőséget adhat a nem tanulmányi - de egyes hallgatók által követendőnek tartott - normakövető viselkedés elkerüléséhez [18]. A család jó anyagi helyzete kedvezően hathat a hallgatói jól-létre. A magas jól-lét érzet és az eredményes tanulás fontos szerepet játszik a tanulási cél melletti kitartásban, a szélesebb kapcsolati háló kialakításában, egyben megkönnyíti a felsőoktatás céljainak a megvalósulását.

A vizsgálat célkitúzése a szakmai tanulmányaik kezdetén lévő hallgatói mintán megvizsgálni - az eredményességi változók tükrében - a hallgatói jól-lét támogató tényezőit az egyetemre való belépés idején. Választ keresni arra, hogy a függő változóként definiált WHO WBI-5 kérdéssor értékeit minként befolyásolják a hallgatói eredményesség, az SWLS-kérdő́ivre adott pontszám értéke, a szülők anyagi helyzete, a sporttevékenység, az egyetemi infrastruktúrával való elégedettség. Vizsgálódtunk a nemek és a lakóhely településtípusa tekintetében is. 


\section{Módszer}

\section{Minta}

A vizsgálatban a Semmelweis Egyetem négy karának ÁOK, FOK, GYTK, EKK - elsőéves hallgatói vettek részt, a 2014-2015-ös tanév első félévében. A hallgatók önkéntes alapon töltötték ki az online kérdőívet, amelyet az egyetemi hálózaton érhettek el. A mintát 377 hallgató adatai alkotják, a következő arányban: ÁOK = $43(11 \%)$, FOK $=161(43 \%)$, GYTK $=102(27 \%)$, EKK $=71(19 \%)$. Az utóbbiak BSc-szinten tanulnak, míg a többiek osztatlan, mesterképzésben, ezért kari kontextusba helyeztük a vizsgálatot. A minta véletlenszerűnek tekinthető a hallgatói kitöltési önkéntesség miatt.

A kérdőív tartalmazta a WHO WBI-5, 5 tételes, négyfokú (Likert-skála 0-3-ig) jól-léti index kérdéssorát, az élettel való elégedettséget mérô skála (SWLS) kérdéssorát, és ezeken kívül még több, a hallgatói életre vonatkozó kérdést is.

A függő változó a szubjektív jól-lét (WHO WBI-5). A magyarázó változók: az élettel való elégedettség (SWLS-pontszám), az egyetemi infrastruktúrával való elégedettség, a sport, a kar, a család szubjektíven megítélt anyagi viszonyai, a lakóhely településtípusa.

Leíró statisztikát, független kétmintás t-tesztet, egy szempontos varianciaanalízist, illetve lineáris regressziót használtunk. A számításokat az SPSS Statistics 23.0 programcsomaggal végeztük.

\section{Méröeszközök}

\section{Általános Jól-lét Index (WHO WBI-5)}

Az Egészségügyi Világszervezet Jól-lét Indexének rövidített változata: 5 tételes, Likert-skála $0-3$, a hallgatók elmúlt két hetére vonatkozóan ad információt. A mérőeszköz magyar populációra való adaptálása és validálása a Hungarostudy 2002 vizsgálat keretein belül történt meg [19].

\section{Élettel Való Elégedettség Skála (Satisfaction With Life Scale)}

A szubjektív pszichikai jól-lét mérésére az élettel való elégedettséget mérő SWLS-skálát alkalmaztuk, amelynek eredetileg három komponense van: elégedettség, kellemes érzések, valamint az utóbbi hiánya [20]. Az ötkérdéses kérdőívvel az elsôt mértük. A skála értékei 1-7-ig terjednek. A kérdésekre adott válaszok összegének maximális pontszáma 7 és 35 pont között mozog [21]. Pozitív megfogalmazású, az elért magasabb pontszám az élettel való magasabb elégedettséget mutat. Az SWLSkérdőív kérdései:

1. Az életem szinte minden területen közel áll a tökéleteshez.

2. Kitűnőek az életkörülményeim.
3. Elégedett vagyok az életkörülményeimmel.

4. Mind ez idáig elértem az általam fontosnak tartott dolgokat az életben.

5. Ha újra leélhetném az életem, szinte semmit sem változtatnék rajta.

A teszt belső konzisztenciája mintánkban jónak mutatkozott (Cronbach-alfa $=0,781$, a Kaiser-Meyer-Olkin $(\mathrm{KMO})$-index $=0,707$; Bartlett-teszt $<0,0001)$.

\section{Szubjektív Hallgatói Eredményességi Index}

Azért hoztuk létre, hogy azonosítani tudjuk a kapcsolati struktúrák által létrejövő - erőforrások által meghatározott - háttértényezőket, amelyek szerepet játszanak a szubjektív eredményesség kedvező alakulásában. Az eredményes hallgatónál kimutatható: az intézményi és tanulmányi folytonosság, a tanulmányok iránti elköteleződés, az involváltság, az akadémiai normák elfogadása, a saját tanulásában való aktív részvétel, a tanulmányi célja melletti kitartás, valamint a munkavállalási és késóbbi továbbtanulási hajlandóság [22]. A képzett öt alcsoport pontszámainak összege adja az „eredményességi pontszámot", amelyből dichotóm változót hoztunk létre, a változó megoszlása alapján: a rendezett pontszám intervallumának alsó kétharmadába az „Átlagos vagy gyengébb”, a felső harmadába az „Eredményesebb” hallgatók kerültek.

\section{Az infrastruktúrával való elégedettség meghatáro- zása}

Vizsgáltuk, hogy a hallgatók milyen mértékben elégedettek az ôket körülvevő infrastruktúrával. A kérdő́ivben 18 kérdés öleli fel (oktatók, a tantárgy érdekessége, gyakorlati helyek, vallásgyakorlási lehetőség stb.) ezt a területet. Az adható válasz értékei $1-4$ közöttiek $(4=$ nagyon elégedett, 1 = nagyon elégedetlen). A kérdésekre adott válaszok összegének maximális pontszáma 0 és 72 pont között változik. A rendezett pontszám intervallumának alsó kétharmadába tartoznak a kevésbé megelégedettek („szerényebb infrastruktúra”), a felső harmadába pedig az elégedett és nagyon elégedett („Gazdagabb infrastruktúra") hallgatók.

\section{Statisztikai analizis}

Az elemzéseket az IBM SPSS Statistics 23.0 programcsomaggal végeztük (SPSS, Chicago, IL). Két csoport összehasonlítására független kétmintás t-tesztet, kettőnél több csoportra pedig egy szempontos varianciaanalízist használtunk. A hatásméret kifejezésére a Hedge-g/ Cohen-d-értéket számítottuk a kapott SPPS-adatok alapján, egy internetes alkalmazás segítségével [23]. Többváltozós analízis során PCA-t és lineáris regressziót alkalmaztuk a hatásos változók szúrésére. Szignifikáns eredménynek a $\mathrm{p}<0,05$ értéket tekintettük. 


\section{Eredmények}

Az öttételes WHO Általános Jól-lét Skála belső megbízhatósága jó, a Cronbach-alfa értéke 0,778.

$\mathrm{Az}$ item-analízisben a megfigyelt változók korrelációi mindenhol szignifikáns eredményt adtak, a reproduced korrelációk 0,35 és 0,70 között mozogtak. A rotálatlan fókomponens-analízis megerősítette a kérdő́iv homogenitását: az egyetlen, egynél nagyobb saját értékú komponens által magyarázott variancia elérte a $53,86 \%$ ot; az egyes kérdések töltéssúlyai pedig 0,60 és 0,83 közöttiek (1. táblázat).

Mintánkban az Általános Jól-lét Skálán az összpontszám férfiaknál szignifikánsan $(\mathrm{p}<0,001)$ magasabb, mint nők esetén (2. táblázat).

A Hedge-g értéke a két csoport közötti különbség mértékét (effect size) jellemzi, ami jelen esetben közepes

1. táblázat | A WHO WBI-5 kérdőív tételeinek jellemző adatai $(\mathrm{n}=377)$ (a skála számértékei 0 és 3 közé esnek)

\begin{tabular}{llll}
\hline $\begin{array}{l}\text { Kérdések: } \\
\text { Az elmúlt két hét során... }\end{array}$ & $\begin{array}{l}\text { PCA-töltés- } \\
\text { súlyok }\end{array}$ & $\begin{array}{l}\text { Reproduced } \\
\text { töltéssúlyok }\end{array}$ & Átlag \pm szórás \\
\hline $\begin{array}{l}\text { 1. Vidámnak } \\
\text { és jókedvünek éreztem } \\
\text { magam. }\end{array}$ & 0,83 & 0,62 & $1,93 \pm 0,75$ \\
\hline $\begin{array}{l}\text { 2. Nyugodtnak } \\
\text { és ellazultnak éreztem } \\
\text { magam. }\end{array}$ & 0,79 & 0,61 & $1,22 \pm 0,83$ \\
\hline $\begin{array}{l}\text { 3. Aktívnak és élénknek } \\
\text { éreztem magam. }\end{array}$ & 0,78 & 0,70 & $1,53 \pm 0,82$ \\
\hline $\begin{array}{l}\text { 4. Ébredéskor frissnek } \\
\text { és kipihentnek éreztem } \\
\text { magam. }\end{array}$ & 0,64 & 0,35 & $0,78 \pm 0,81$ \\
\hline $\begin{array}{l}\text { 5. A napjaim tele voltak } \\
\text { számomra érdekes } \\
\text { dolgokkal. }\end{array}$ & 0,60 & 0,41 & $1,72 \pm 0,75$ \\
\hline
\end{tabular}

2. táblázat |A WHO WBI-5 kérdőív összpontszámának összehasonlítása ne mek szerint

\begin{tabular}{|c|c|c|c|c|c|c|c|}
\hline $\mathrm{Nem}$ & $\mathrm{n}$ & $\begin{array}{l}\text { Átlag } \\
\pm \text { szórás }\end{array}$ & $\mathrm{t}$ & $\mathrm{df}$ & $\begin{array}{l}\text { Sig. } \\
\text { (2-tailed) }\end{array}$ & $\begin{array}{l}95 \% \\
\text { CI értékei }\end{array}$ & Hedge-g \\
\hline Férfi & 114 & $8,02 \pm 2,86$ & \multirow{2}{*}{3,87} & \multirow{2}{*}{375} & \multirow{2}{*}{0,000} & \multirow{2}{*}{$0,60 \quad 1,8$} & \\
\hline Nő & 263 & $6,80 \pm 2,82$ & & & & & $0, \mathrm{TO}$ \\
\hline
\end{tabular}

3. táblázat |A WHO WBI-5 kérdőív összpontszámának összehasonlítása településtípusok szerint

\begin{tabular}{lclll}
\hline Település típusa & $\mathrm{n}$ & Átlag \pm szórás & Minimum & Maximum \\
\hline $\begin{array}{l}\text { Tanya, falu, } \\
\text { község }\end{array}$ & 60 & 7,1000 & 0,00 & 15,00 \\
\hline Kisebb város & 116 & 7,2155 & 0,00 & 15,00 \\
\hline $\begin{array}{l}\text { Megyeszékhely, } \\
\text { fóváros }\end{array}$ & 201 & 7,1642 & 0,00 & 15,00 \\
\hline Összes & 377 & 7,1698 & 0,00 & 15,00 \\
\hline
\end{tabular}

4. táblázat $\mid$ A WHO WBI-5 kérdőív összpontszámának összehasonlítása karok szerint

\begin{tabular}{lrlll}
\hline Kar kódja & \multicolumn{1}{l}{$\mathrm{n}$} & Átlag \pm szórás & Minimum & Maximum \\
\hline ÁOK & 43 & $7,84 \pm 3,03$ & 1,00 & 12,00 \\
FOK & 161 & $6,70 \pm 2,88$ & 0,00 & 15,00 \\
GYTK & 102 & $7,10 \pm 2,5$ & 0,00 & 13,00 \\
EKK & 71 & $7,93 \pm 3,14$ & 1,00 & 15,00 \\
\hline Összes & 377 & $7,20 \pm 2,88$ & 0,00 & 15,00 \\
\hline
\end{tabular}

5. táblázat |A WHO WBI-5 kérdőív összpontszámának összehasonlítása sportolás szerint

\begin{tabular}{|c|c|c|c|c|c|c|c|}
\hline $\begin{array}{l}\text { Rend- } \\
\text { szeresen } \\
\text { sportol }\end{array}$ & $\mathrm{n}$ & $\begin{array}{l}\text { Átlag } \pm \\
\text { szórás }\end{array}$ & $\mathrm{t}$ & df & $\begin{array}{l}\text { Sig. } \\
\text { (2-tailed) }\end{array}$ & $\begin{array}{l}95 \% \text { CI } \\
\text { értékei }\end{array}$ & Hedge-g \\
\hline Nem & 311 & $\begin{array}{l}7,02 \\
\pm 2,86\end{array}$ & \multirow{2}{*}{$-2,12$} & \multirow{2}{*}{375} & \multirow{2}{*}{0,035} & \multirow{2}{*}{$-1,58-0,06$} & \multirow{2}{*}{0,29} \\
\hline Igen & 66 & $\begin{array}{l}7,85 \\
\pm 2,93\end{array}$ & & & & & \\
\hline
\end{tabular}

erôsségû: az index a Cohen-d alternatív változata erősen eltérő mintaszám esetén.

Településtípusonként vizsgálva a WHO WBI-5 kérdőiv megoszlását adódik, hogy ha nem is szignifikáns mértékben, de a „Tanya, falu, község” településtípus átlagpontszáma alacsonyabb, mint a másik két településtípus - „Kisebb város” és a „Megyeszékhely, főváros” - esetén (Levene-teszt $\mathrm{p}=0,598$, a csoportok varianciája homogénnek tekinthető, ANOVA: $\mathrm{F}=0,032, \mathrm{p}=0,968)$ (3. táblázat).

Karok között vizsgálva a kérdőív megoszlását, megkapjuk, hogy az egy szempontos ANOVA szignifikáns eltérést ad: Levene-teszt $\mathrm{p}=0,598$ (a karok között a varianciája homogén), $\mathrm{F}=3,934, \mathrm{p}=0,009$. A Bonferroni post hoc használata alapján a FOK-EKK karok között szignifikáns $(\mathrm{p}<0,016)$ az eltérés az EKK hallgatói számára: a Hedge-g értéke a két csoport között közepes erôsségú $(0,42)$ (4. táblázat).

Megvizsgálva a sporttal való kapcsolatot, szignifikáns eredményt kapunk a rendszeresen sportolók javára, Hedge-g = 0,29 (5. táblázat).

Nagyon érdekes a hallgatói eredményességgel kapcsolatos eredmény. Azok a hallgatók mutatkoznak eredményesebbnek, akiknek a WHO WBI-5 kérdőív összpontszáma magasabb, azaz akiknek az általános jól-lét érzete magasabb. A Hedges-g értéke $(0,33)$ a két csoport közötti közepes erősségú eltérést mutat az „Eredményesebb" hallgatók javára (6. táblázat).

Azoknál a hallgatóknál magasabb az általános jól-lét érzet, akik magasabbnak ítélik az egyetemi infrastruktúrát, mert feltehetően jobban élnek ezekkel a lehetőségekkel. A Hedge-g értéke $(0,588)$ a két csoport közötti jó közepes erősségú eltérést mutat a "Gazdagabb infrastruktúra” megítélésủ hallgatók javára (7. táblázat). 
6. táblázat |A WHO WBI-5 kérdőív összpontszámának összehasonlítása a hallgatói eredményesség szerint

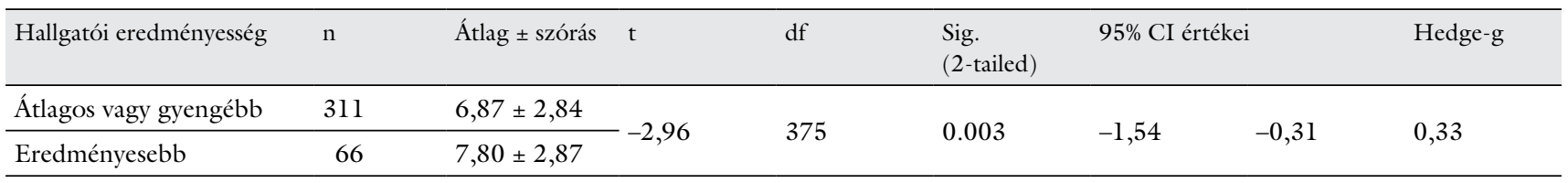

7. táblázat |A WHO WBI-5 kérdőív összpontszámának összehasonlítása az egyetemi infrastruktúrával való elégedettség szerint

\begin{tabular}{llllll}
\hline Egyetemi infrastruktúrával való elégedettség & $\mathrm{n}$ & Átlag \pm szórás $\mathrm{t}$ & $\mathrm{df}$ & $\begin{array}{l}\text { Sig. } \\
(2 \text {-tailed })\end{array}$ & $\begin{array}{l}\text { Hedge-g } \% \text { CI értékei } \\
\text { Szerényebb infrastruktúra }\end{array}$ \\
\hline Gazdagabb infrastruktúra & 172 & $6,28 \pm 2,85$ \\
\hline
\end{tabular}

8. táblázat |A WHO WBI-5 kérdőív regressziós vizsgálata

\begin{tabular}{|c|c|c|c|c|c|c|}
\hline \multirow[t]{2}{*}{ Változók } & \multicolumn{2}{|c|}{ Nem standardizált együtthatók } & \multirow{2}{*}{$\begin{array}{l}\text { Standardizált } \\
\text { együtthatók }\end{array}$} & \multirow[t]{2}{*}{ Szignifikancia } & \multirow{2}{*}{$\begin{array}{l}\text { Parciális } \\
\text { korreláció }\end{array}$} & \multirow{2}{*}{$\begin{array}{l}\text { Variancia- } \\
\text { infláló faktor } \\
\text { (VIF) }\end{array}$} \\
\hline & $\mathrm{B}$ & Standard hiba & & & & \\
\hline Constant & 4,159 & 1,119 & & 0,000 & & \\
\hline Kar & 0,568 & 0,156 & 0,182 & 0,000 & 0,186 & 1,166 \\
\hline Nem & $0-1,405$ & 0,295 & $-0,224$ & 0,000 & $-0,241$ & 1,032 \\
\hline SWLS H & 0,147 & 0,026 & 0,280 & 0,000 & 0,282 & 1,150 \\
\hline Szülők anyagi helyzete & $-0,265$ & 0,105 & $-0,119$ & 0,012 & $-0,131$ & 1,038 \\
\hline Sporttevékenység & 0,681 & 0,373 & 0,090 & 0,068 & 0,095 & 1,132 \\
\hline Egyetemi infrastruktúrával való elégedettség & 1,231 & 0,277 & 0,213 & 0,000 & 0,225 & 1,071 \\
\hline
\end{tabular}

Stepwise lineáris regressziós elemzéssel (célváltozónk a WBI-5 függő változó) kiszürtük azokat a magyarázó változókat, amelyek a legjobban befolyásolják a függő változót (8. táblázat).

\section{A WHO WBI-5 pontszámának becslö egyenlete}

WHO WBI-5 = 4,159+0,568 Kar - 1,405 Nem + 0,147 SWLS_H - 0,265 Szülök anyagi helyzete + 0,681 Sporttevékenység + 1,231 Egyetemi infrastruktúrával való elégedettség

A regresszióban $\left(\mathrm{R}=0,458, \mathrm{R}^{2}=0,21, \mathrm{~F}=16,33, \mathrm{p}=\right.$ $0,001)$ minden változó hatása szignifikáns, a VIF (variance inflation factor, varianciainfláló faktor) értékei jók, a változók ortogonálisak, nincs a változók között lineáris függvényszerü kapcsolat, azaz multikollinearitás (9. táblázat).

\section{Megbeszélés}

Az elsőéves hallgatók körében nem reprezentatív mintán alkalmazott és elemzett WHO WBI-5 kérdőív tételeinek belső konzisztenciája jó (Cronbach-alfa: 0,778). A kérdőív rotálatlan főkomponens-elemzése megerősíti a kér- dőív homogenitását, az adatbázis használhatóságát (Kaiser-Meyer-Olkin-index [KMO $]=0,748$; Bartlett-teszt $<0,0001)$.

A hallgatók neme szerint a WHO WBI-5 kérdőív Hedge-g, értéke a két csoport között közepes erősségű, a férfiak esetében az érték magasabb, a férfiak jobban érzik magukat az egyetemen.

A település típusa ugyan szignifikáns módon nem befolyásolja ( $\mathrm{p}=0,968)$ a WHO WBI-5 kérdőív megoszlását, de a „Tanya, falu, község” településtípus esetén az átlag pontszáma alacsonyabb, mint a másik két település esetén ( Kisebb város”, „Megyeszékhely, főváros”).

A négy kar között a WHO WBI-5 kérdőív szignifikáns eltérést adott a FOK-EKK karok között $(\mathrm{p}<0,016$, a Hedge-g értéke közepes erósségú $[0,42])$ : az EKK hallgatói jobban érzik magukat. A másik három kar hallgatói között nincs szignifikáns eltérés, a hallgatók egyformán ítélik meg helyzetüket az egyetemen. A sporttevékenység pozitívan hat a WHO WBI-5 értékeire.

A hallgatói egyetemi eredményességet vizsgálva azt találtuk, hogy azok a hallgatók mutatkoznak eredményesebbnek, akiknek a WHO WBI-5 kérdőív összpontszáma magasabb, azaz akiknek a jól-lét érzete magasabb (Hedge-g = 0,33 közepes erősségü eltérést mutat az „Eredményesebb” hallgatók javára). 


\section{9. táblázat | Összefoglaló táblázat}

\begin{tabular}{|c|c|c|}
\hline Változó & $\begin{array}{l}\text { B együttható } \\
\text { előjele }\end{array}$ & $\begin{array}{l}\text { Magyarázó változó hatása a függő } \\
\text { változóra }\end{array}$ \\
\hline Kar & + & $\begin{array}{l}\text { A kar kódjának sorszáma szerint } \\
\text { növekvő a WBI értéke is. }\end{array}$ \\
\hline Hallgató neme & - & $\begin{array}{l}\text { A férfiaknál a WBI értéke } \\
\text { magasabb. }\end{array}$ \\
\hline SWLS-pontszám & + & $\begin{array}{l}\text { Élettel való elégedettség } \\
\text { értékének növekedése a WBI } \\
\text { értékét is növeli. A legjobban } \\
\text { befolyásoló tényezó a } \\
\text { standardizált } \beta \text {-értékek szerint, } \\
\text { mivel itt van a legnagyobb érték. }\end{array}$ \\
\hline $\begin{array}{l}\text { Szülők anyagi } \\
\text { helyzete }\end{array}$ & - & $\begin{array}{l}\text { Az alacsonyabb anyagi helyzetű } \\
\text { szülők gyermekeinek jobb a } \\
\text { WBI-értéke. }\end{array}$ \\
\hline Sporttevékenység & + & A sport emeli a WBI értékét. \\
\hline $\begin{array}{l}\text { Egyetemi } \\
\text { infrastruktúrával } \\
\text { való elégedettség }\end{array}$ & + & $\begin{array}{l}\text { Az egyetemi infrastruktúrával } \\
\text { való elégedettség emeli a WBI } \\
\text { értékét. }\end{array}$ \\
\hline
\end{tabular}

Kar kódja: 1. ÁOK, 2. FOK, 3. GYTK, 4. EKK.

Nem: 1 = férfi; 2 = nő.

SWLS-pontszám: A kérdőív 5 tételére adott pontszámok összege.

Szülők anyagi helyzete: 1 = átlagnál gyengébb, 2 = átlagos, 3 = átlagnál valamivel jobb, 4 = jó, 5 = nagyon jó.

Sporttevékenység: 1 = nem sportol, 2 = rendszeresen sportol.

Egyetemi infrastruktúrával való elégedettség: 1 = szerényebb infrastruktúra, 2 = gazdagabb infrastruktúra.

Lineáris regresszió alkalmazásával $\left(\mathrm{R}=0,458, \mathrm{R}^{2}=\right.$ $0,21, \mathrm{~F}=16,33, \mathrm{p}=0,0001$, a VIF-értékek 1 körüliek) kiszürtük a hallgatói válaszokból azokat a magyarázó változókat, amelyek a legjobban befolyásolják a függő változó WHO WBI-5 értékét. A modellben a nem (a férfiak jobban érzik magukat az egyetemen), a kar (az ÁOKhoz viszonyítva sorrendben jobban érzik magukat a FOK, GYTK, EKK kar hallgatói), SWLS-pontszám (minél magasabb az Élettel Való Elégedettség Skála értéke, annál magasabb a WHO WBI-5 értéke is) változók között egyértelmú a pozitív kapcsolat. A parciális korreláció értéke is itt a legmagasabb, azaz 0,282, a szülők anyagi helyzete (érdekes, hogy az alacsonyabb anyagi helyzetben lévő szülők gyermekeinek jobb a WHO WBI-5 kérdőív értéke, ók jobban értékelik, jobban hatnak rájuk az egyetemi körülmények), a sporttevékenység (a rendszeres sporttevékenység pozitívan befolyásolja a WHO WBI-5 kérdôív értékét), az egyetemi infrastruktúrával való elégedettség (azoknak a hallgatóknak magasabb a WHO WBI-5 kérdő́iv értéke, akik az egyetemi infrastruktúrát magasabbnak értékelik, ösztönzóleg hat a pozitív egyetemi körülmény a jól-lét érzésre).

Látható, hogy a jól-léti koncepció erkölcsi, emberi képesség és eredményességi szempontból fogalmazódik meg. Az egyetemi évek alatt, a szakmai felkészülés idején fontos a hallgatók számára, hogy olyan mikrokörnyezetben éljenek, amely segít kialakítani a felelős viselkedést és felkészít a felelős szakmai munkára. A tanulmányok meg- kezdésekor a hallgatóknak - különösen - sok külső segítségre van szüksége ahhoz, hogy eredményesek lehessenek a tanulmányaikban, és a magas szintű jól-lét érzés ennek meglétét tanúsíthatja.

Anyagi támogatás: A közlemény megírása és a kutatómunka anyagi támogatásban nem részesült.

Szerzői munkamegosztás: D. Sz. M.: Mint doktoranda végezte a kérdóíves felmérést, annak statisztikai feldolgozását, a dolgozat összeállítását, megírását. P. G.: Témavezetőként mentori segítséget adott, és részt vett a szövegezésben. A cikket mindketten elolvasták és jóváhagyták.

Érdekeltségek: A szerzőknek nincsenek érdekeltségeik.

\section{Irodalom}

[1] Stewart-Brown, S., Evans, J., Patterson, J., et al.: The health of students in institutes of higher education: an important and neglected public health problem? J. Public Health Med., 2000, 22(4), 492-499.

[2] Awartani, M., Whitman, C. V., Gordon, J.: Developing instruments to capture young people's perceptions of how school as a learning environment affects their well-being. Eur. J. Educ., 2008, 43(1), 51-70.

[3] Pusztai, G.: From the invisible hand to friendly hands. Interpretive communities of students in higher education. [A láthatatlan kéztől a baráti kezekig. Hallgatói értelmező közösségek a felsőoktatásban.] Új Mandátum Kiadó, Budapest, 2011. [Hungarian]

[4] WHO Health Definition. http://www.who.int/about/definition/en/print.html

[5] Central Statistical Office: The well-being indicator system in Hungary, 2013. [Központi Statisztikai Hivatal: A jóllét magyarországi indikátorrendszere, 2013.] Központi Statisztikai Hivatal, 2014. http://www.ksh.hu/docs/hun/xftp/idoszaki/pdf/jollet13.pdf [Hungarian]

[6] Diener, E., Emmons, R. A., Larsen, R. J., et al.: The Satisfaction with Life Scale. J. Personality Assessment, 1985, 49(1), 71-75.

[7] Hellivell, J. F.: Well-being and social capital: Does suicide pose a puzzle? National Bureau of Economic Research, Cambridge, 2004.

[8] Bates, M. J., Bowles, S. V.: Review of well-being in the context of suicide prevention and resilience. RTO-MP-HFM-205, DTIC Document, 2011. http://www.dtic.mil/

[9] Pusztai, G., Baltatescu, S., Kovacs, K., et al.: Social capital and student well-being in higher education. A theoretical framework. Hungarian Educ. Res. Assoc., 2012, 2(1), 54-73.

[10] Pusztai, G.: School and community: High school sectarian turn of the millennium. [Iskola és közösség: Felekezeti középiskolások az ezredfordulón.] Gondolat Kiadó, Budapest, 2004. [Hungarian]

[11] Fredrickson, B.: The power of positive emotions. [A pozitív érzelmek hatalma.] Akadémiai Kiadó, Budapest, 2015. [Hungarian]

[12] Masters, G. N.: "Conceptualising and researching student wellbeing”, 2004. http://research.acer.edu.au/research_conference_2004/1

[13] Csíkszentmihályi, I., Csikszentmihályi, I. S.: Live well! [Élni jó!] Akadémiai Kiadó, Budapest, 2011. [Hungarian] 
[14] Kopp, M., Skrabski, Á., Szedmák, S.: Psychosocial risk factors, inequality and self-rated morbidity in a changing society. Soc. Sci. Med., 2000, 51(9), 1351-1361.

[15] Pikó, B.: Mission of positive psychology in modern society. [A pozitív pszichológia missziója a modern társadalomban.] Mentálhigiéné és Pszichoszomatika, 2004, 5(4), 289-299. [Hungarian]

[16] Kovács, K.: Sport activity as a supportive factor in higher education. [A sportolás mint támogató faktor a felsőoktatásban.] Oktatáskutatók Könyvtára 2. Debrecen, 2015. [Hungarian]

[17] Pikó, B. (ed.): Protective factors footsteps. Health promotion and prevention of substance abuse in adolescence. [Védőfaktorok nyomában. A káros szenvedélyek megelőzése és egészségfejlesztés serdülő́korban.] L’Harmattan Kiadó, Budapest, 2010. [Hungarian]

[18] Kopp, M., Székely, A., Skrabski, Á.: Religion and health in changing society. [Vallásosság és egészség az átalakuló társadalomban.] Mentálhigiéné és Pszichoszomatika, 2004, 5(2), 103-125. [Hungarian]

[19] Rózsa, S., Réthelyi, J., Stauder, A., et al.: The general Hungarostudy 2002 nationally representative survey methodology and a psychometric test battery used features. [A Hungarostudy 2002 országos reprezentatív felmérés általános módszertana és a felhasznált tesztbattéria pszichometriai jellemzói.] Psychiatria Hungarica, 2003, 18(2), 83-94. [Hungarian]

[20] Diener, E.: Subjective well-being: Three decades of progress. Psychological Bulletin, 1999, 125(2), 276-302.

[21] Diener, E.: Subjective well-being. Psychological Bulletin, 1984, 95(3), 542-575.

[22] Pusztai, G.: Not inevitable, only uncertain for eye. Concepts and indicators for student's efficiency in higher education research. In: Nagy, P. T., Veroszta, Zs. (eds.): Higher education research. [„Nem biztos csak a kétes a szememnek...” Hallgatói eredményességi koncepciók és mutatók a felsőoktatás-kutatásban. In: Nagy, P. T., Veroszta, Zs. (szerk.): A felsőoktatás kutatása.] Gondolat Kiadó, Budapest, 2014. [Hungarian]

[23] Effect Size Calculator for T-Test. http://www.socscistatistics. com/effectsize/Default3.aspx

(Dinyáné Szabó Mariann, Budapest, Tamási Áron u. 18., 1124 e-mail: dinyane.mariann@public.semmelweis-univ.hu)

\section{Szakorvosi állás}

A Szent Margit Rendelőintézet bőrgyógyász szakorvost keres, azonnali belépéssel, teljes vagy részmunkaidőben, akár vállalkozási formában.

Fényképes önéletrajzot a következő email címre várunk:

thomka.gyorgy@obudairendelok.hu 